\title{
SHEAR TESTS ON SNOW EXPLAINED BY FAST METAMORPHISM
}

\author{
By VinCENT DE MONTMOLLIN* \\ (Laboratoire d'Applications Spéciales de la Physique D.T.C.E., Centre d'Études Nucléaires de \\ Grenoble, 85X 38041 Grenoble Cedex, France)
}

\begin{abstract}
Shear tests performed on natural snow exhibited three kinds of behaviour with increasing shear rate: (1) viscous, without failure, (2) brittle of the first kind (cycles of brittle failure), (3) brittle of the second kind (only one brittle failure, and solid friction). These results can be explained by fast metamorphism of the bond system during the tests. When the shear rate is low, bonds can be regenerated after their destruction, and this regeneration is less active as the shear rate increases.
\end{abstract}

RÉSUMÉ. Interprétation de tests de cisaillement par une métamorphose rapide du système des ponts. Nous avons procédé à des essais de cisaillement sur de la neige naturelle et retrouvé les trois types de comportement: (1) visqueux, sans rupture, (2) fragile du premier type (cycles de ruptures fragiles), (3) fragile du second type (une seule rupture fragile, suivie d'un frottement solide). Tous les résultats s'expliquent en admettant une métamorphose rapide du système des ponts au cours même des essais. Quand la vitesse de sollicitation est faible, les points peuvent se reconstituer au fur et à mesure qu'ils sont détruits. C'est de moins en moins possible quand la vitesse augmente.

ZuSAMMENFASSUNG. Scherversuche an Schnee und ihre Erklärung durch schnelle Metamorphose. Scherversuche mit natürlichem Schnee zeigen drei Verhaltensweisen bei zunehmender Scherrate: (1) viskos ohne Bruch, (2) spröde von der ersten Art (Zyklen von spröden Brüchen), (3) spröde von der zweiten Art (nur ein spröder Bruch mit fester Reibung). Diese Ergebnisse können durch schnelle Metamorphose des Verbundsystems während der Versuche erklärt werden. Bei geringer Scherrate können die Bindungen nach ihrer Zerstörung erneurt werden, die Fähigkeit zur Erneuerung nimmt mit wachsender Scherrate ab.

\section{INTRODUCTION}

It is accepted that mechanical properties of a given snow depend overall on the mechanical, and therefore morphological, properties of the bond system (St Lawrence and Bradley, [1975]; Kry, 1975; Gubler, 1978). However to characterize it is often very difficult. Density and temperature may be of considerable influence, but cannot give a good indication of the state of the bond system, and for this reason results which did not consider the bond system differ widely (Landauer, 1957; Yosida and others, 1955-58; Ramseier and Pavlak, 1964; Feldt and Ballard, 1965; Ballard and Feldt, 1965; Kinosita, 1967; Shinojima, 1967; Mellor and Smith, 1967; Keeler, 1969; Yong and Fukue, 1977).

Some authors (Kingery and Berg, 1955; Yosida and others, 1955-58; Hobbs and Mason, 1964; Hobbs, 1965; Hobbs and Radke, 1967; Radke and Hobbs, 1967) have shown that time, temperature, and stress state govern the morphological evolution of the bonds, and that this evolution can be very fast. However, all these authors consider that this metamorphism is insignificant during tests.

The results presented here are interpreted by making the hypothesis that there are fast processes acting locally on the structure of the bond system during tests. This phenomenon is termed fast age-hardening, or fast metamorphism. As we shall see, Yosida's results on the influence of compression rate during compression tests support this hypothesis.

For technical and theoretical reasons, shear tests are easier to carry out and to interpret. Two kinds of instrument (and their results) are presented here: a shear box and a rotating apparatus called "bevametre". Both devices may be used with various constant shear rates.

* Present address: Laboratoire de Glaciologie, 2 rue Très-Cloîtres, 38031 Grenoble Cedex, France. 
YOSIDA AND OTHERS' COMPRESSION TESTS

Yosida and others (1955-58) carried out compression tests, using various constant compression rates, on snows of densities between 370 and $400 \mathrm{~kg} \mathrm{~m}^{-3}$. Compression rates were within 2 and $600 \mathrm{~mm} \mathrm{~min}^{-1}\left(0.33 \times 10^{-4}\right.$ and $\left.10^{-2} \mathrm{~m} \mathrm{~s}^{-1}\right)$. More recently other authors (Kinosita, 1966; Shinojima, 1966) have obtained similar results.

All these tests show three kinds of behaviour: for a compression rate $V$ less than $V^{\prime}$ (first critical compression rate) there is no failure, but a linearly increasing stress, the stress for a given strain being greater when $V$ tends to $V^{\prime}$. For $V$ between $V^{\prime}$ and a second critical compression rate $V^{\prime \prime}$, cycles of failures appear, each stress peak on the curve stress versus time corresponding to the destruction of a slice of snow in the upper part of the sample. Stress intensity at each peak is independent of the number of peaks, but decreases as $V$ increases from $V^{\prime}$ to $V^{\prime \prime}$. The number of these peaks is limited by the height of sample used. When $V$ is greater than $V^{\prime \prime}$, there is only one peak (one failure) followed by a level stress. The compression strength (stress intensity at the peak) appears to be independent of the compression rate. This property can be used to determine a mechanical parameter, the compression strength, which, for a compression rate great enough, only depends on the morphological characteristics of the snow tested.

Yosida called these three behaviours plastic compression and destructive compression of the first and second kind. The author prefers the terms viscous behaviour and brittle behaviour of the first and the second kind, according to the terminology used in soil mechanics (Fig. 1).

Yosida showed that the behaviour depended on the compression rate and not on the strainrate. This, and the fact that his samples increased in density in the viscous range and were destroyed in the two brittle ranges, made it impossible for him to interpret his tests as a whole. These results may nevertheless be interpreted considering the fast metamorphism of the bond system. If the compression rate is low enough, the evolution of the bond system (i.e. the growth of existing bonds, creation of new bonds, etc.) is fast enough to avoid microscopic stress accumulation: the increase of the microscopic stresses is compensated by the increase of the dimensions and number of bonds. There is no failure. Because the density of the snow sample increases, the macroscopic stress does not remain constant; in tests which allow density to remain constant, the proposed hypothesis should lead to a constant stress. If the compression rate is higher, the metamorphism of the bond system remains active, but there is no relaxation of the high stresses, which cause failure. The greater the compression rate, the smaller the influence of the fast metamorphism phenomenon, and the smaller the compression strength. If the compression rate is great enough, fast metamorphism is inactive, and the compression strength is no longer dependent on the compression rate, provided there is no classical viscosity.

Therefore, Yosida's compression tests may be interpreted by fast bond-system evolution, but densification and heterogeneities in tested samples impede any quantitative interpretation. For

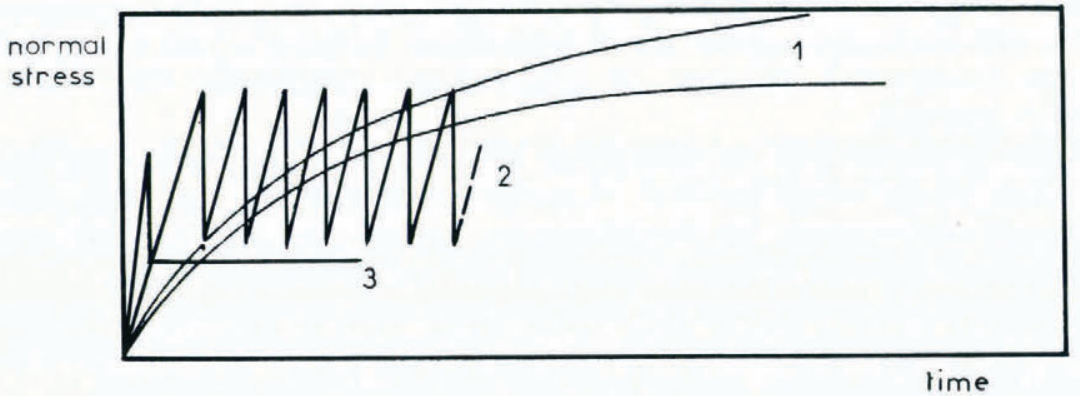

Fig. 1. The three kinds of behaviour in Yosida's compression tests: (1) viscous behaviour, (2) brittle behaviour of the first kind, (3) brittle behaviour of the second kind. 
this reason, shear tests with various constant shear rates (i.e. displacement rates of the upper part of the samples sheared, the lower part remaining steady) have been carried out.

\section{Previous WORK ON SHEARING}

There is much literature concerning shear strength (Butkovitch, 1958[a], [b]; Ballard and McGaw, 1966; Roch, 1966; Ballard and others, 1965; Martinelli, 1971; Perla, 1977; McClung, 1977). With the exception of Ballard and others (1965) and McClung (1977), tests were performed at constant shear rates or constant stress rates and failure was always obtained. In these tests, only one peak (one failure) was apparent. Ballard and others used shear strength as an index of bonds development during the classical (slow) metamorphism, and the main body of their tests was carried out at a constant shear rate $\left(18 \mathrm{~mm} \mathrm{~min}^{-1}\right.$, i.e. $\left.3 \times 10^{-4} \mathrm{~m} \mathrm{~s}^{-1}\right)$. They attempted to test the influence of shear rate in some of their tests, but the rates used only ranged between 6 and $36 \mathrm{~mm} \mathrm{~min}^{-1}\left(10^{-4}-6 \times 10^{-4} \mathrm{~m} \mathrm{~s}^{-1}\right)$. They obtained no qualitative differences, only a slight diminution of the shear strength when the shear rate was large, which is consistent with the hypothesis of fast metamorphism (de Montmollin, 1979). McClung (1977) used shear rates in the range $0.15-0.0022 \mathrm{~mm} \mathrm{~min}^{-1}\left(2.5 \times 10^{-6}-3.7 \times 10^{-8} \mathrm{~m} \mathrm{~s}^{-1}\right)$, obtaining no failure, but almost constant shear stresses.

Shear tests are very advantageous for checking our hypothesis: it is possible, with some care, to avoid significant densification, and the localization of the phenomena (shear with or without failure) is favourable. There are some disadvantages, the main one being the impossibility of determining the rheological law, but our investigation was purely qualitative. On interpreting shear-box tests, the velocity field on a surface parallel to the shear surface is currently assumed to be uniform, which is impossible when a rotating shearing apparatus is used. It is generally possible to assume that the non-uniformity of the velocity field has no influence.

We devised three instruments. The first is an in-situ rotating apparatus called a "manual bevametre". It is used to test the validity of rotating shear tests and to determine the parameters of the intrinsic curves of various snows. Its validity has been proved to be satisfactory (de Montmollin, 1979). The second is a classical shear box allowing various shear rates. The third is a more sophisticated rotating shear apparatus called "mechanical bevametre".

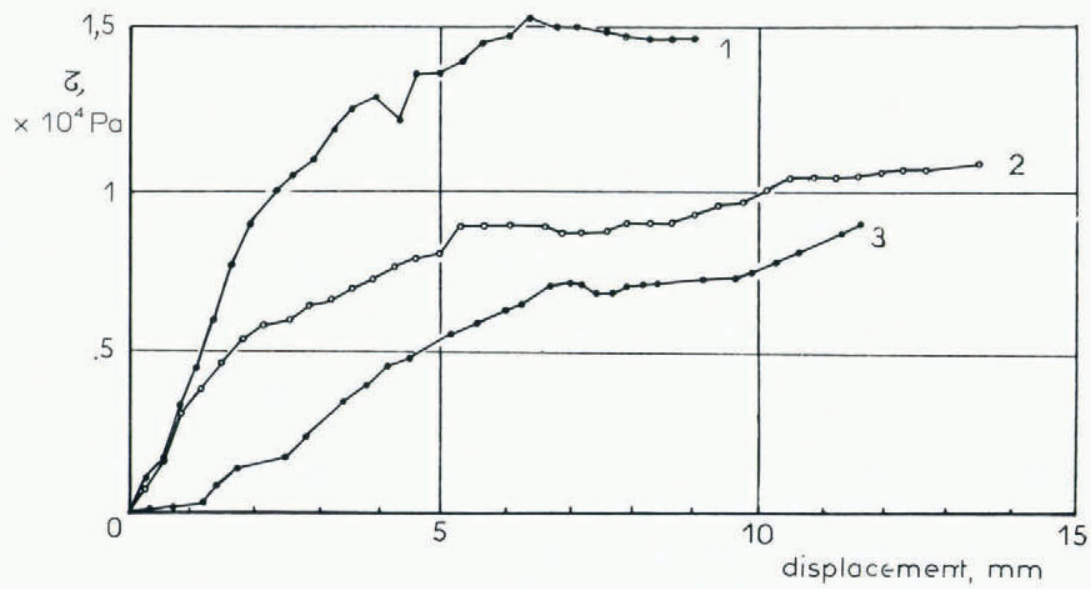

Fig. 2. Shear-box tests at constant shear rate on a fine-grained snow, density $300 \mathrm{~kg} \mathrm{~m}{ }^{-1}$, temperature about $0^{\circ} \mathrm{C}$, shear stress versus displacement for a shear rate of $1.5 \mathrm{~mm} \mathrm{~min}^{-1}\left(2.5 \times 10^{-5} \mathrm{~m} \mathrm{~s}^{-1}\right)$ : (1) normal stress $4.3 \times$ $10^{3} \mathrm{~Pa}$, (2) normal stress $2.1 \times 10^{3} \mathrm{~Pa}$, (3) normal stress $0.61 \times 10^{3} \mathrm{~Pa}$. 


\section{SHEAR-BOX TESTS}

The box used was a classical shear box with a $10 \times 10 \mathrm{~cm}^{2}$ sample surface. Shear rates ranged between 0.2 and $9 \mathrm{~mm} \mathrm{~min}^{-1}\left(0.33 \times 10^{-5}\right.$ and $\left.0.15 \times 10^{-3} \mathrm{~m} \mathrm{~s}^{-1}\right)$, normal stresses between 0 and $43 \mathrm{mbar}\left(0\right.$ and $\left.4.3 \times 10^{3} \mathrm{~Pa}\right)$; shear stresses may rise up to $300 \mathrm{mbar}$ $\left(3 \times 10^{4} \mathrm{~Pa}\right)$. The measurements were performed manually. The snow used for the tests was not uniform, due to the impossibility of storing snow under good conditions. In spite of this, the results were very interesting. Figure 2 represents tests carried out on fine-grained snow (density $300 \mathrm{~kg} \mathrm{~m}^{-3}$, temperature $0^{\circ} \mathrm{C}$ ) with the same low shear rate of $1.5 \mathrm{~mm} \mathrm{~min}^{-1}(2.5 \times$ $10^{-5} \mathrm{~m} \mathrm{~s}^{-1}$ ) and various normal stresses. There was no failure. The larger the normal stress, the larger was the shear stress, because bond formation had been favoured. Figure 3 represents tests carried out on a fresh snow (density $170 \mathrm{~kg} \mathrm{~m}^{-3}$, temperature $-1^{\circ} \mathrm{C}$ ), with a constant shear rate of about $9 \mathrm{~mm} \mathrm{~min}^{-1}\left(1.5 \times 10^{-4} \mathrm{~m} \mathrm{~s}^{-1}\right)$. Failures appeared, and then the stress dropped to a steady low value. Figure 4 represents tests carried out on a round-grained snow (density $430 \mathrm{~kg} \mathrm{~m}^{-3}$, temperature $\left.0^{\circ} \mathrm{C}\right)$ with a shear rate of about $4 \mathrm{~mm} \mathrm{~min} \operatorname{mon}^{-1}\left(6.7 \times 10^{-5} \mathrm{~m} \mathrm{~s}^{-1}\right)$. Here brittle failure occurred, and the shear stress after failure was negligible.

Therefore the existence of two different behaviours has been demonstrated; viscous behaviour (in which, as suggested, a constant shear stress at constant density is reached), and brittle failures with or without a residual steady stress after the failure. Because of the variety of the snows which were tested, it is difficult to envisage the limits of the viscous and brittle domains. (Let us note that, since failures are not plastic but brittle, Mohr's criterion, which is a

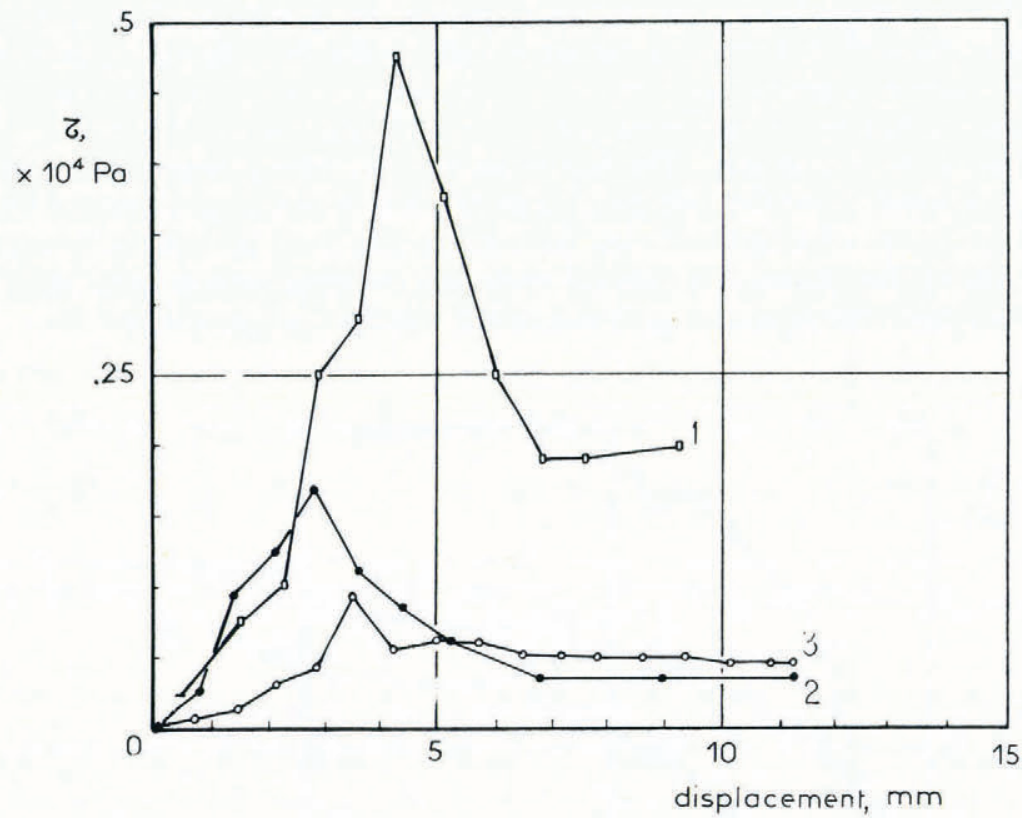

Fig. 3. Shear box tests at constant shear rate on a fresh snow, density $170 \mathrm{~kg} \mathrm{~m}^{-3}$, temperature $-1^{\circ} \mathrm{C}$, shear stress versus displacement with the following parameters:

$\begin{array}{cccc}\text { Curve no. } & \begin{array}{c}\text { Normal stress } \\ \mathrm{Pa}\end{array} & \begin{array}{c}\text { Shear rate } \\ \mathrm{mm} \mathrm{min}^{-1}\end{array} & \begin{array}{c}\text { Shear rate } \\ \mathrm{m} \mathrm{s}^{-1}\end{array} \\ 1 & 2.8 \times 10^{3} & 9.3 & 1.55 \times 10^{-4} \\ 2 & 0 & 9.0 & 1.50 \times 10^{-4} \\ 3 & 0.61 \times 10^{3} & 8.7 & 1.45 \times 10^{-4}\end{array}$




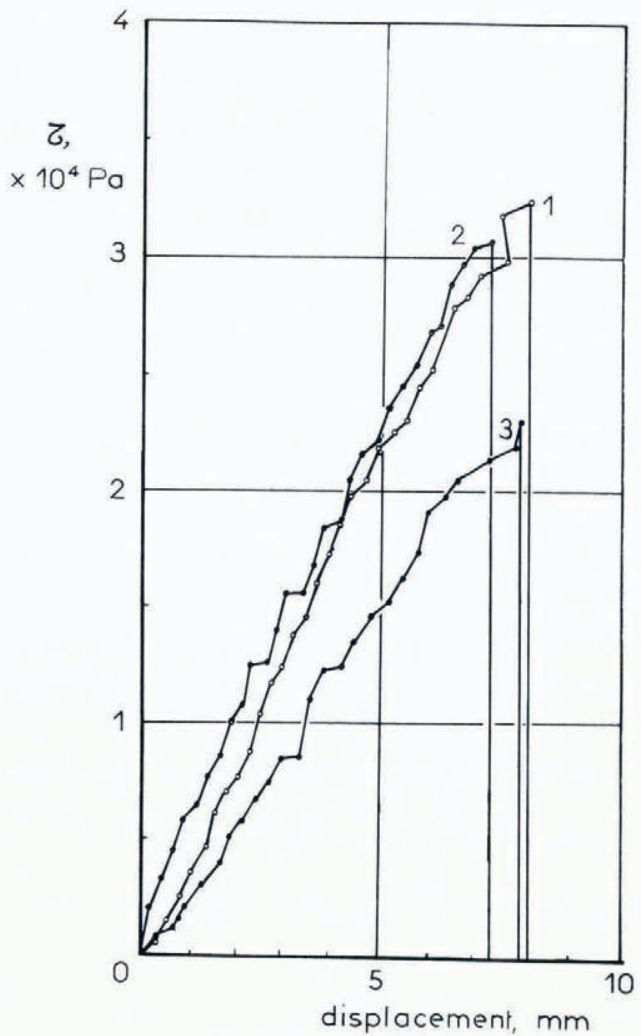

Fig. 4. Shear box tests at constant shear rate on a round-grained snow, density $430 \mathrm{~kg} \mathrm{~m}^{-3}$, temperature $0^{\circ} \mathrm{C}$, shear stress versus displacement with the following parameters:

$\begin{array}{cccc}\text { Curve no. } & \text { Normal stress } & \text { Shear rate } & \text { Shear rate } \\ 1 & \mathrm{~Pa} & \mathrm{~mm} \mathrm{~min}^{-1} & \mathrm{~m} \mathrm{~s}^{-1} \\ 2 & 2.3 \times 10^{3} & 4.0 & 6.7 \times 10^{-5} \\ 3 & 1.2 \times 10^{3} & 4.0 & 6.7 \times 10^{-5} \\ & 0 & 4.5 & 7.5 \times 10^{-5}\end{array}$

plastic criterion, is not applicable. Intrinsic curves often described in the literature cannot be treated as Mohr's curves.)

The first critical shear rate seemed to be within the range 1 to $5 \mathrm{~mm} \mathrm{~min}^{-1}$ range $\left(1.67 \times 10^{-5}\right.$ to $\left.8.33 \times 10^{-5} \mathrm{~m} \mathrm{~s}^{-1}\right)$. The existence of a second critical shear rate was not demonstrated, at any rate no cyclic failures appeared, probably because of the low rigidity of the loading system.

\section{BEVAMETRE TESTS}

This equipment (Figs 5 and 6) uses circular heads to shear snow along a horizontal plane only. Three shear heads were used; the best proved to be a crowned head with an inside diameter of $35 \mathrm{~mm}$ and an outside diameter of $80 \mathrm{~mm}$ (the second head in Fig. 5). The validity of the results obtained with a rotating shear head was checked by comparison with classical instruments: shear frame and shear box on snow, triaxial apparatus and shear box on standard sands and glass-ball media. In the mechanical bevametre, rotation is obtained by a step-by-step motor 


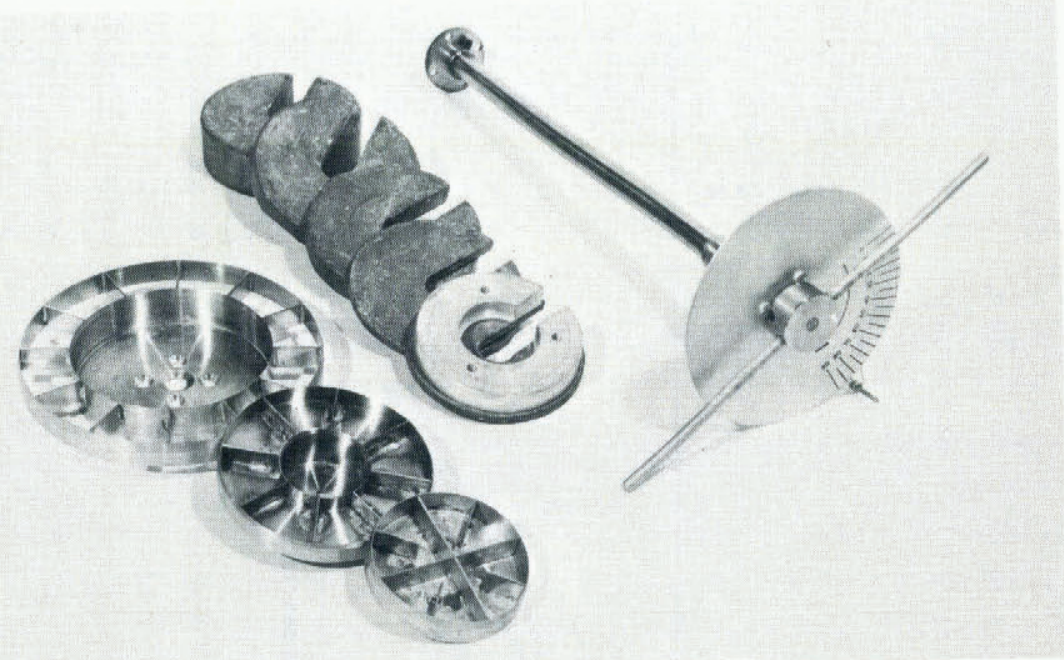

Fig. 5. The manual bevametre, from left to right: the body of the apparatus, the lead masses, the shear heads (which were also used for the mechanical bevametre).

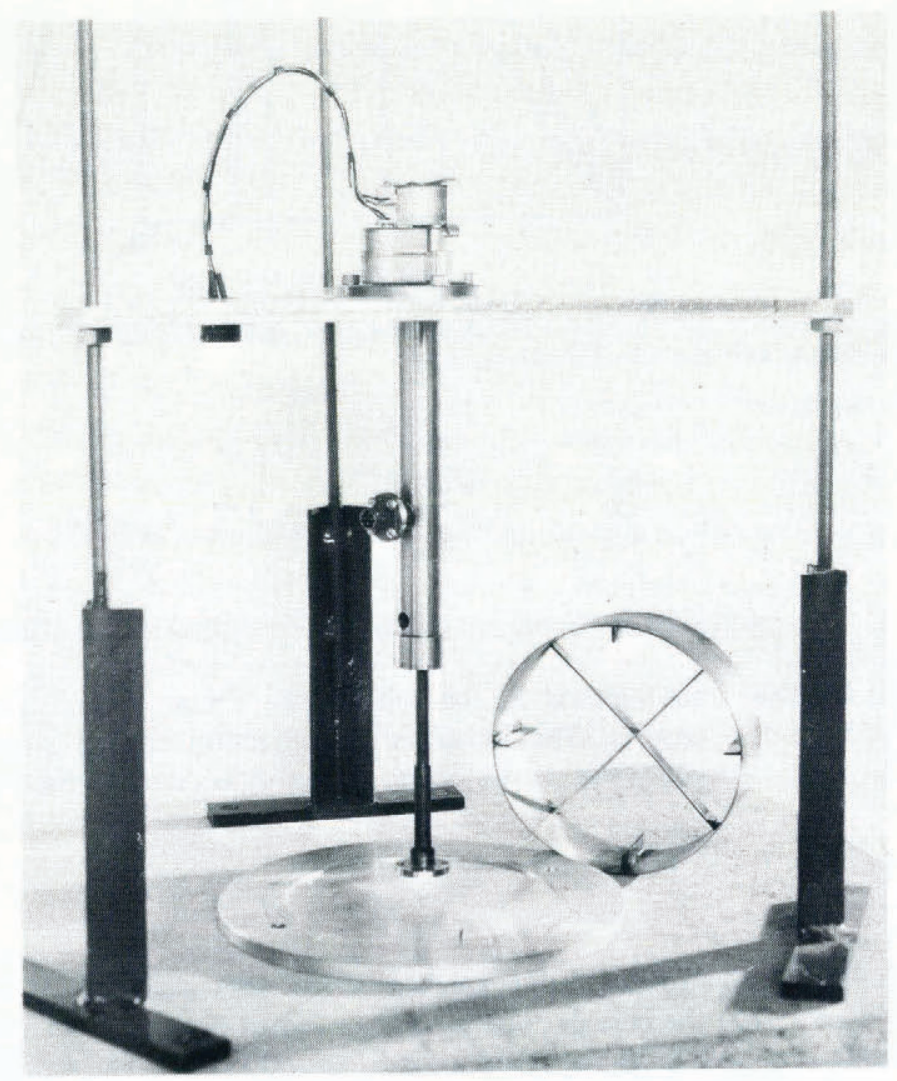

Fig. 6. The mechanical bevametre, from top to bottom: the motor and the speed reducer fixed on the frame, the tube protecting the torsion rod and the strain gauges, the exit of the signal from the strain gauges, and the vertically sliding part. The sampling mould is to the right of the picture. 
TABLE I. SHEAR RATES AND SHEAR ROTATION RATES FOR THE CROWNED HEAD USED FOR THE TESTS WITH THE MECHANICAL BEVAMETRE. THE LINEAR SHEAR RATE INCREASES FROM $V_{\min }$ AT THE SMALLEST RADIUS TO $V_{\max }$ AT THE LARGEST

$\begin{array}{lllcc}\begin{array}{c}\text { Motor command } \\ \text { frequency }(\mathrm{Hz})\end{array} & 0.2 & 2 & 20 & 200 \\ \text { Rotation rate (r.p.m.) } & 0.00075 & 0.0075 & 0.075 & 0.75 \\ V_{\min }\left(\mathrm{mm} \mathrm{min}^{-1}\right) & 0.0825 & 0.825 & 8.25 & 82.5 \\ V_{\max }\left(\mathrm{mm} \mathrm{min}^{-1}\right) & 0.1885 & 1.885 & 18.85 & 188.5\end{array}$

coupled with a speed reducer $1 / 800$. There is no gear-box, but electronic control. Rotation rates varied from 0.00075 r.p.m. to 0.75 r.p.m. $\left(1.25 \times 10^{-5}\right.$ to $\left.1.25 \times 10^{-2} \mathrm{~Hz}\right)$. The corresponding linear shear rates (which vary along the radius) are given in Table I. The thickness of the sheared slice is unknown.

The torque was measured with strain gauges glued on the drive shaft which acted as a torsion rod. Shear stress was assumed to be uniform along the radius of the sheared surface. The motor can be used not only for tests at constant rotation rates (which are described in this paper), but also as a servo-motor for tests at constant torque (constant shear stress). Lead masses can be used to obtain constant normal stresses on the sheared surface. Tests were carried out in situ, in the field just after sampling, or in the cold room, with the sample mould seen in Figure 6.

Two similar snows were tested: fine-grained snow, density $200 \mathrm{~kg} \mathrm{~m}^{-1}$, temperature $-3^{\circ} \mathrm{C}$ (snow A), and fine-grained snow, density $190 \mathrm{~kg} \mathrm{~m}^{-1}$, temperature $-6^{\circ} \mathrm{C}$ (snow B).

Rotation rate 0.75 r.p.m. $\left(1.25 \times 10^{-2} \mathrm{~Hz}\right)$

For all the tests carried out at this rate, we obtained a marked stress peak (on the curves of stress versus time or stress versus rotation angle) followed by a progressive stress diminution leading to a constant stress level (Fig. 7). Thus failure always happened. In this way a relationship between shear strength and normal stress for this rotation rate was obtained (Fig. 8). The curves of stress versus time obtained were comparable with the curves of stress versus time of Yosida and others (1958) for their compression tests in the brittle domain of the second kind.

Rotation rate 0.075 r.p.m. $\left(1.25 \times 10^{-3} \mathrm{~Hz}\right)$

For this rotation rate, brittle failure cycles were obtained; after each failure, the stress did not drop to zero (Fig. 9). The intensity of the stress peak was largest at the beginning of the test, and the existence of minima and maxima of the shear strength (reproducible from one test to the other) was not explained. The brittle failure cycles do not appear to be dependent on the total rotation (about $150^{\circ}$ for the test plotted in Fig. 9), but only on the rotation rate. The curves of stress versus time so obtained were comparable with Yosida's curves of compression stress versus time in the brittle domain of the first kind.

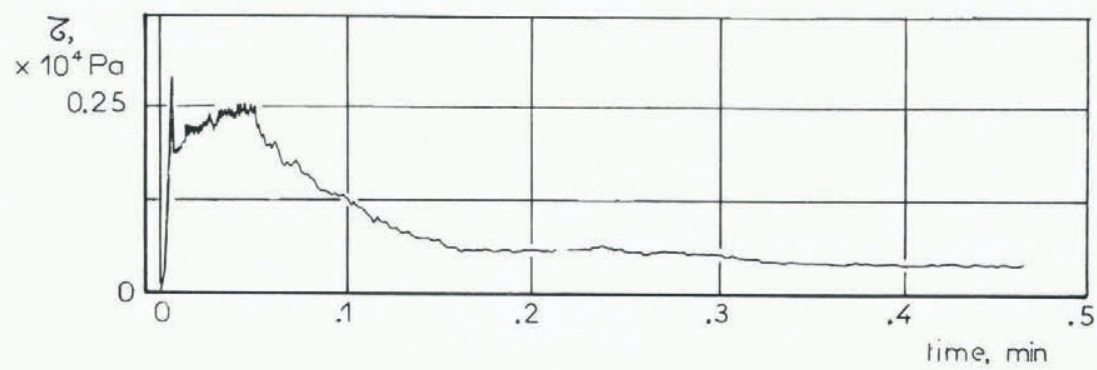

Fig. 7. Mechanical bevametre, relation between shear stress and time for snow A, with a normal stress of $8.5 \times 10^{2}$ $\mathrm{Pa}$, and rotation rate $r_{\mathrm{r}}=0.75$ r.p.m. $\left(1.25 \times 10^{-2} \mathrm{~Hz}\right)$. 


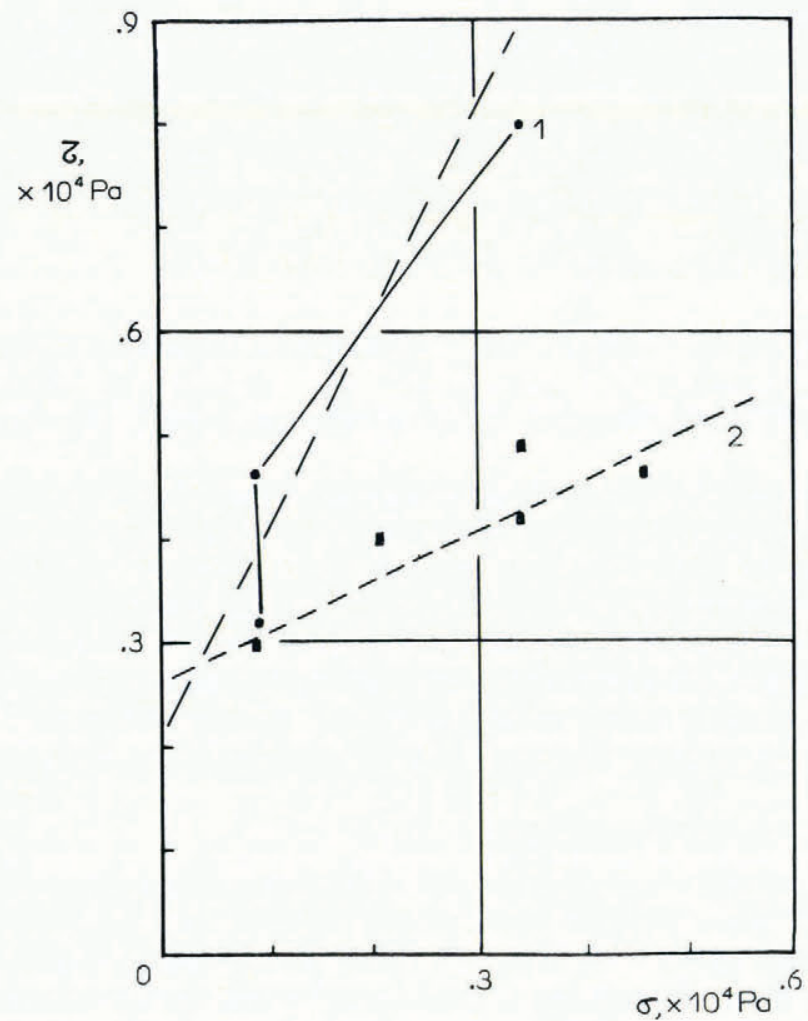

Fig. 8. Mechanical bevametre, relation between peak shear strength and normal stress for snows $A$ (curve no. 1 ) and $B$ (curve no. 2), for a rotation rate $r_{\mathrm{r}}=0.75$ r.p.m. $\left(1.25 \times 10^{-2} \mathrm{~Hz}\right)$.

Rotation rate 0.0075 r.p.m. $\left(1.25 \times 10^{-4} \mathrm{~Hz}\right)$

Two kinds of behaviour were obtained for this rotation rate: either a viscous behaviour (Fig. 10) or a brittle behaviour with a very high shear strength (see next paragraph). In the viscous domain, it is possible to obtain large rotations with a constant stress: this suggests the existence of a surface of velocity discontinuity (or at least a zone of great velocity gradient), the "shear surface", but no material discontinuity. In this particular material and case, a "surface" of velocity discontinuity may have existed without any failure occurring. This was due to the fast metamorphism (disappearance, creation, displacement) of the bonds. In many tests performed at this rate, the shear stress became too great for the apparatus, and the rotation had to be stopped.

\section{Tests with various constant rotation rates}

When alternating 0.075 r.p.m. $\left(1.25 \times 10^{-3} \mathrm{~Hz}\right)$ rotations and rests, curves of stress versus time of the kind shown in Figure 11 are obtained. When the rotation rate is 0 , the stress relaxes with time according to the empirical relation

$$
\tau=\tau_{\max } \exp \left[\left(\frac{-t}{T_{\mathrm{r}}}\right)^{\alpha}\right]
$$

where $\alpha$ lies between 0.34 and 0.69 and $T_{\mathrm{r}}$ between 3.5 and $27 \mathrm{~min}$. After a relaxation, the stress at the first peaks is larger, but the mean peak stress is the same after and before the relaxation. 


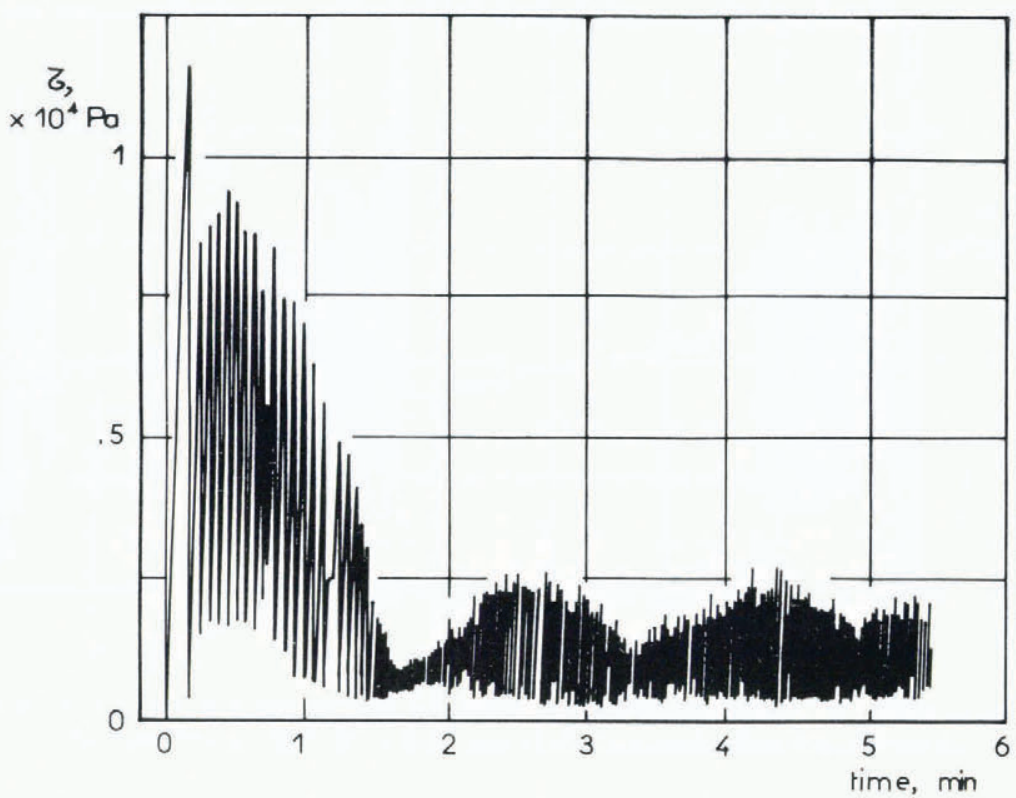

Fig. 9. Mechanical bevametre, relation between shear stress and time for snow A, with a normal stress of $8.5 \times$ $10^{2} \mathrm{~Pa}$, and rotation rate $r_{\mathrm{r}}=0.075$ r.p.m. $\left(1.25 \times 10^{-3} \mathrm{~Hz}\right)$.

In the test represented on Figure 12, the initial rotation rate was $r_{\mathrm{r}}=0.0075$ r.p.m. $\left(1.25 \times 10^{-4} \mathrm{~Hz}\right)$. Failure appeared with a large strength, and the stress then dropped to zero (total failure). After a short time, the stress climbed again, and the motor had to be stopped. Stress relaxation was allowed for $28 \mathrm{~min}\left(\alpha=0.381\right.$ and $\left.T_{\mathrm{r}}=23.7 \mathrm{~min}\right)$. Next the motor was restarted at a swifter rotation rate $r_{\mathrm{r}}=0.075$ r.p.m. There was a first brittle failure with a high stress, and then brittle failure cycles essentially identical with those occurring in tests with this rotation rate from the beginning. After about three minutes and 140 cycles, the rotation rate was

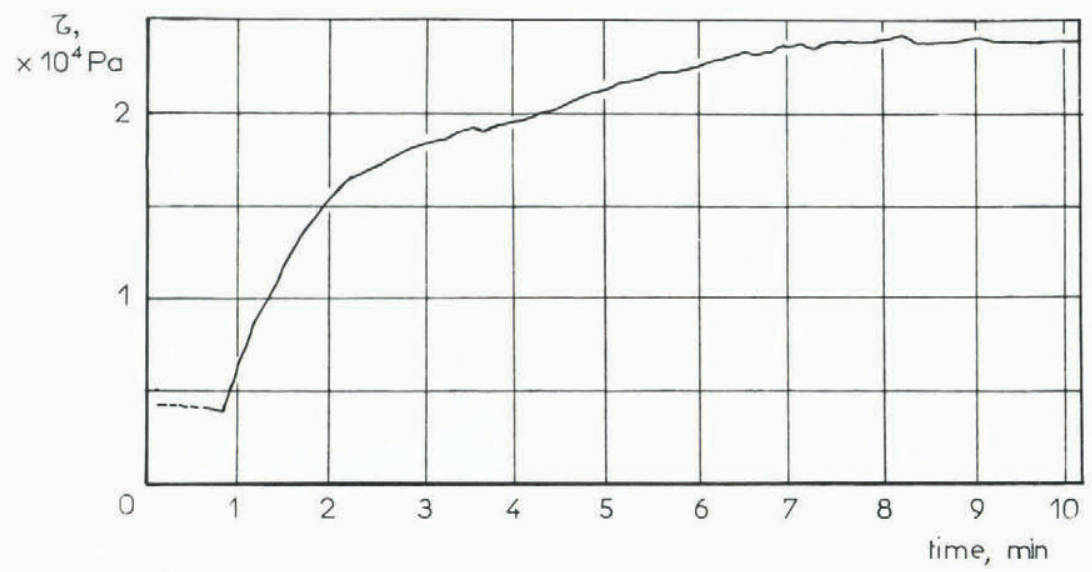

Fig. 10. Mechanical bevametre, relation between shear stress and time for snow $B$, with normal stress of $8.5 \times$ $10^{2} \mathrm{~Pa}$, and rotation rate $r_{\mathrm{r}}=0.0075$ r.p.m. $\left(1.25 \times 10^{-4} \mathrm{~Hz}\right)$. The first part of this test, which is not represented here, was carried out at 0.0075 r.p.m. with no failure, followed by a relaxation. 


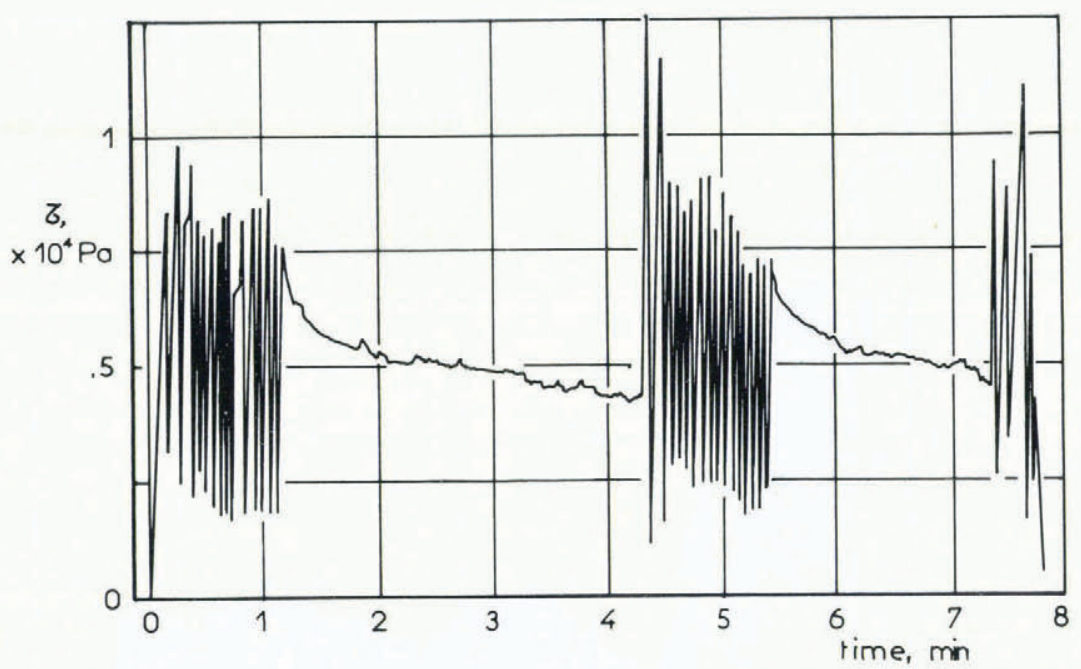

Fig. 11. Mechanical bevametre, relation between shear stress and time for snow B, with a normal stress of $3.3 . \times$ $10^{3} \mathrm{~Pa}$, and rotation rate alternating between 0.075 r.p.m. $\left(1.25 \times 10^{-3} \mathrm{~Hz}\right)$ and 0 (relaxation).

increased again to 0.75 r.p.m.; a constant stress level was then obtained.

In all these tests, the behaviour of a snow sample at a given rotation rate is essentially identical with that observed during tests on the same snow which had had the same given rotation rate during the whole test. Not all the configurations of increasing-decreasing rotation rates were tested, but the results (for complete results see Montmollin, 1979) suggest that the successive mechanical behaviours of a given snow sample depend only on the rotation rate, not on the previous rotation rates. This is coherent with Salm's (1971) results on compression.

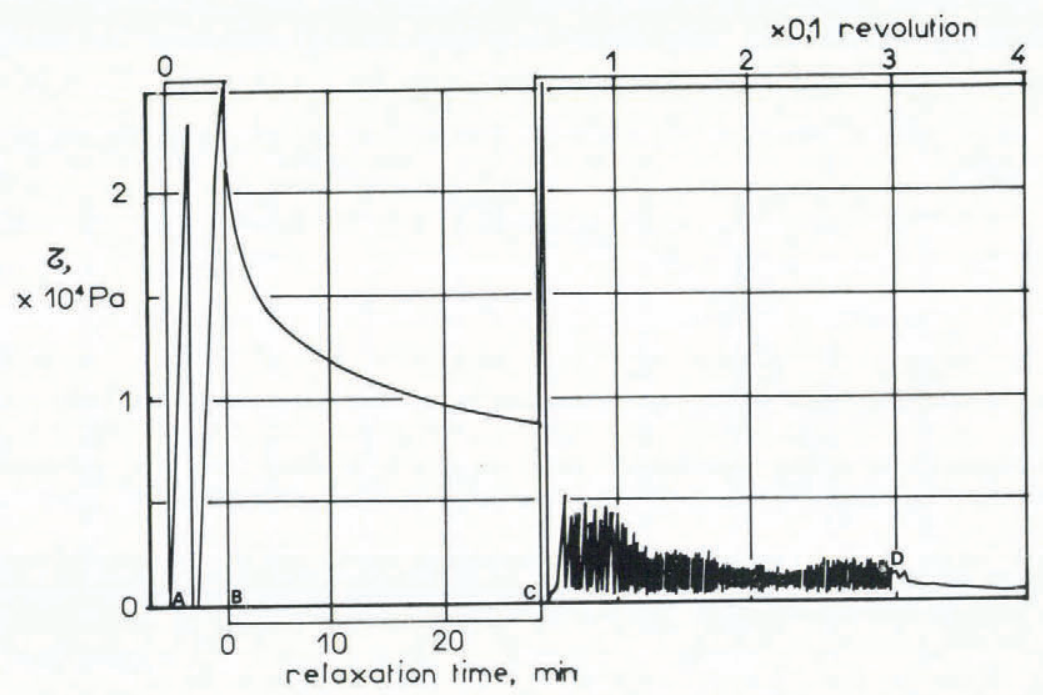

Fig. 12. Mechanical bevametre, relation between shear stress and time or the number of revolutions for snow $A$, with a normal stress of $8.5 \times 10^{2} \mathrm{~Pa}$ and rotation rate successively $r_{\mathrm{r}}=0.0075$ r.p.m. $\left(1.25 \times 10^{-4} \mathrm{~Hz}\right)(\mathrm{AB}), r_{\mathrm{r}}=0$ $(B C$, relaxation $), r_{\mathrm{r}}=0.075$ r.p.m. $\left(1.25 \times 10^{-3} \mathrm{~Hz}\right)(C D)$ and $r_{\mathrm{r}}=0.75$ r.p.m. $\left(1.25 \times 10^{-2} \mathrm{~Hz}\right)$. 


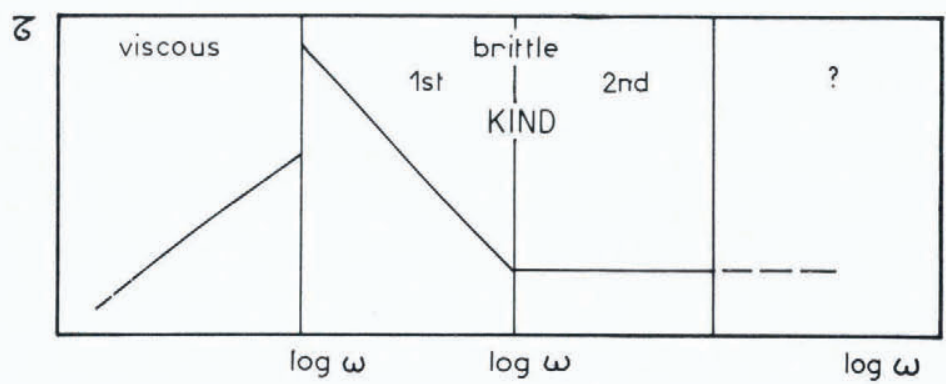

Fig. 13. Shear strength (or constant shear stress level in the viscous domain) versus rotation rate.

\section{DISCUSSION}

The different types of behaviour are represented in Figure 13. These tests could be interpreted in the same way as Yosida's tests, but here there was neither densification nor destruction of the samples. The validity of the proposed hypothesis of fast metamorphism is reinforced by the following: after each brittle failure, bonds are quickly regenerated to allow the test to go on. In the cycles of brittle failures, this regeneration allows the shear stress not to drop to zero. In the same way, the greatest shear strength is obtained when the rotation rate is slightly larger than the first critical rotation rate: fast metamorphism is very active and reinforces the bond system during the test, but not enough to avoid the final failure. The stress measurement system is not rigid enough, and no further measurable stress level is obtained.

\section{CONCLUSION}

The three kinds of behaviour which are observed in shear tests may be interpreted as due to fast processes changing the structure of the bond system.

It seems then that snow mechanics, even for the "short" durations of laboratory or field tests, should be interpreted in terms of mechanics and thermodynamics of the bond system. Many results of soil mechanics appear to be inapplicable to snow, because the instability of the skeleton in snow has no equivalent. Snow mechanics must necessarily develop separately.

\section{MS. received 19 November 1979 and in revised form 11 August 1980}

\section{REFERENCES}

Ballard, G. E. H., and Feldt, E. D. 1965. Considerations of the strength of snow. U.S. Cold Regions Research and Engineering Laboratory. Research Report 184.

Ballard, G. E. H., and McGaw, R. W. 1966. A theory of snow failure. Union de Géodésie et Géophysique Internationale. Association Internationale d'Hydrologie Scientifique. Commission pour la Neige et la Glace. Division Neige Saisonnière et Avalanches. Symposium international sur les aspects scientifiques des avalanches de neige, 5-10 avril 1965, Davos, Suisse, p. 160-69. (Publication No. 69 de l'Association Internationale d'Hydrologie Scientifique.)

Ballard, G. E. H., and others. 1965. Direct shear study on snow. Procedure and data, by G. E. H. Ballard, E. D. Feldt, and S. R. Toth. U.S. Cold Regions Research and Engineering Laboratory. Special Report 92.

Butkovich, T. R. 1958[a]. Strength studies of high-density snow. U.S. Snow, Ice and Permafrost Research Establishment. Research Report 18.

Butkovich, T. R. 1958[b]. Strength studies of high-density snow. Transactions. American Geophysical Union, Vol. 39 , No. 2, p. 305-12.

Feldt, E. D., and Ballard, G. E. H. 1965. An approach to the consolidation of snow. U.S. Cold Regions Research and Engineering Laboratory. Research Report 181.

Gubler, H. 1978. Determination of the mean number of bonds per snow grain and of the dependence of the tensile strength of snow on stereological parameters. Journal of Glaciology, Vol. 20, No. 83, p. 329-41.

Hobbs, P. V. 1965. The effect of time on the physical properties of deposited snow. Journal of Geophysical Research, Vol. 70, No. 16, p. 3903-07. 
Hobbs, P. V., and Mason, B. J. 1964. The sintering and adhesion of ice. Philosophical Magazine, Eighth Ser., Vol. 9, No. 98 , p. $181-97$.

Hobbs, P. V., and Radke, L. F. 1967. The role of volume diffusion in the metamorphism of snow. Journal of Glaciology, Vol. 6, No. 48, p. 879-91.

Keeler, C. M. 1969. Some physical properties of alpine snow. U.S. Cold Regions Research and Engineering Laboratory. Research Report 271.

Kingery, W. D., and Berg, M. 1955. Study of the initial stages of sintering solids by viscous flow. Journal of Applied Physics, Vol. 26, No. 10, p. 1205-12.

Kinosita [i.e. Kinoshita], S. 1967. Compression of snow at constant speed. (In Ōura, H., ed. Physics of snow and ice: international conference on low temperature science. ... 1966... Proceedings, Vol. 1, Pt. 2. [Sapporo], Institute of Low Temperature Science, Hokkaido University, p. 911-27.)

Kry, P. R. 1975. The relationship between the visco-elastic and structural properties of fine-grained snow. Journal of Glaciology, Vol. 14, No. 72, p. 479-500.

Landauer, J. K. 1957. Creep of snow under combined stress. U.S. Snow, Ice and Permafrost Research Establishment. Research Report 41.

McClung, D. M. 1977. Direct simple shear tests on snow and their relation to slab avalanche formation. Journal of Glaciology, Vol. 19, No. 81, p. 101-09.

Martinelli, M.,jr. 1971. Physical properties of alpine snow as related to weather and avalanche conditions. U.S. Dept. of Agriculture. Forest Service. Research Paper RM-64.

Mellor, M., and Smith, J. H. 1967. Creep of ice and snow. (In Ōura, H., ed. Physics of snow and ice: international conference on low temperature science. ... 1966. ... Proceedings, Vol. 1, Pt. 2. [Sapporol, Institute of Low Temperature Science, Hokkaido University, p. 843-55.)

Montmollin, V. de. 1979. Introduction à la rhéologie de la neige. Commissariat à l'Energie Atomique, Centre d'Études Nucléaires de Grenoble, Laboratoire d'Applications Spéciales de la Physique/DTCE, Rapport CEA No. R. 4993.

Perla, R. I. 1977. Slab avalanche measurements. Canadian Geotechnical Journal, Vol. 14, No. 2, p. $206-13$.

Radke, L. F., and Hobbs, P. V. 1967. The strength-density relationship for dry snow. Journal of Glaciology, Vol. 6, No. 48, p. 893-96.

Ramseier, R. O., and Pavlak, T. L. 1964. Unconfined creep of polar snow. Journal of Glaciology, Vol. 5, No. 39, p. $325-32$.

Roch, A. 1966. Les déclenchements d'avalanches. Union de Géodésie et Géophysique Internationale. Association Internationale d'Hydrologie Scientifique. Commission pour la Neige et la Glace. Division Neige Saisonnière et Avalanches. Symposium international sur les aspects scientifiques des avalanches de neige, 5-10 avril 1965, Davos, Suisse, p. 182-95. (Publication No. 69 de l'Association Internationale d'Hydrologie Scientifique.)

St Lawrence, W., and Bradley, C. C. [1975.] The deformation of snow in terms of a structural mechanism. [Union Géodésique et Géophysique Internationale. Association Internationale des Sciences Hydrologiques. Commision des Neiges et Glaces.] Symposium. Mécanique de la neige. Actes du colloque de Grindelwald, avril 1974 , p. 155-70. (IAHS-AISH Publication No. 114.)

Salm, B. 1971. On the rheological behaviour of snow under high stresses. Contributions from the Institute of Low Temperature Science, Hokkaido University, Ser. A, No. 23.

Shinojima, K. 1967. Study on the visco-elastic deformation of deposited snow. (In Oura, H., ed. Physics of snow and ice: international conference on low temperature science. ... 1966. ... Proceedings, Vol. 1, Pt. 2. [Sapporo], Institute of Low Temperature Science, Hokkaido University, p. 875-907.)

Yong, R. N., and Fukue, M. 1977. Performance of snow in confined compression. Journal of Terramechanics, Vol. 14 , No. 2, p. 59-82.

Yosida, Z. [i.e. Yoshida, J.], and others. 1955-58. Physical studies on deposited snow, by. Z. Yosida [and 6 others]. I-IV. Contributions from the Institute of Low Temperature Science (Sapporo), No. 7, p. 19-74; No. 9, p. 1-81; No. 11 , p. $1-41$; No. 13 , p. 55-100. 